\title{
Association between the Selected Independent Variables and the Knowledge Level of Farmers about Recommended Production Technology of Fennel
}

\author{
Sunil Kumar Sharma ${ }^{1}$, N.K. Sharma ${ }^{2}$, Anand Kumar ${ }^{1}$ and Deepak Chaturvedi ${ }^{3}$ \\ ${ }^{1}$ Agriculture Research Station, SKRAU, Bikaner (Rajasthan), India \\ ${ }^{2}$ Department of Extension Education SKNAU Jobner, Jaipur (Rajasthan), India \\ ${ }^{3}$ Department of Extension Education SKRAU, Bikaner, India \\ *Corresponding author:
}

A B S T R A C T

K e y w o r d s
Fennel growers,
Association,
Knowledge,
Significant,
Non-significant.
Article Info
Accepted:
25 April 2017
Available Online:
10 May 2017

Seed spices occupy prominent place in the total basket of spices of the country and play a significant role in our national economy. The group of spices account for about 37 per cent and 18 per cent of the total area and production of spices in the country, respectively. Fennel (Foeniculum vulgare) commonly known as 'Saunf' is an important and highly valued spice grown in India. This crop is widely grown throughout the temperate and subtropical region of the world for its aromatic fruits used in various food preparations such as soups, meat dishes, sauces, pastries, confectionaries, pickles, liquors etc. The fennel seeds are aromatic, stimulants and carminative. Rajasthan is the third largest producer of spices in the country and accounts for $12.48 \%$ of the total production of major spices. The major fennel producing districts of Rajasthan are Nagaur, Sirohi, Jalore, Dausa, Tonk, Sawai Madhopur and contribute above 90 per cent of area and production of fennel crop. Fennel is an important commercial cash crop of arid and semi arid region. There is a wide scope to improve and increase the fennel production and productivity by enhancing the knowledge and adoption of fennel production technology. The present study was conducted in eight villages (four villages from Mertacity tehsil and four villages from Degana tehsil) in Nagaur district of Rajasthan. A sample of 120 fennel growers was selected from these selected villages by using simple random sampling with proportion sample method. The results indicated that the age, education and annual income were found to be positive and significantly associated with the knowledge level of farmers about fennel production technology. While, the variables like, caste, size of land holding, family type and family size were found to be non-significantly associated with the knowledge level of farmers about fennel production technology.

\section{Introduction}

India is known the world over as 'The Home of Spices', thus Spices and condiments need no introduction. The climate of the country is ideal for the growth of almost all spices. Spices are an important group of agricultural goods, which are virtually indispensable in the culinary art.
They also play a significant role in our national economy and also in the economies of several spice producing, exporting and importing countries. India accounts for about $45 \%$ of the global spice exports. In India, from the point of view of both domestic consumption and export, spices are important commercial crops. 
Seed spices occupy prominent place in the total basket of spices of the country and play a significant role in our national economy. The group of spices accounts for about 37 per cent and 18 per cent of the total area and production of spices in the country, respectively. Seed spices are mainly cultivated in the states of Rajasthan, Gujarat, Andhra Pradesh, and Madhya Pradesh. Among these fennel, coriander, cumin, fenugreek, and Ajwain are cultivated on sizeable acreage as compared to other spices. It is the world's largest producer, consumer and exporter of seed spices which are being cultivated widely in the country over different agro climatic zones. Seed spices are not only for home consumption but also for improving economic status of the farmers. In India fennel is cultivated over an area of 1,00,000 ha with the production of 1,43,000 MT and productivity of $1,430 \mathrm{~kg} / \mathrm{ha}$ (Anonymous. 2010-11).

Fennel (Foeniculum vulgare) commonly known as 'Saunf' is an important dominant and highly valued spice grown in India. This crop is widely grown throughout the temperate and subtropical region of the world for its aromatic fruits used in various food preparations such as soups, meat dishes, sauces, pastries, confectionaries, pickles and liquors etc. The fennel seeds are aromatic, stimulants and carminative.

Fennel oil is used as a flavoring agent in various culinary preparation, confectionary cordials and liquors. The percentage volatile oil in seed varies from 1.5 to 3.5 per cent. It contains 14-22 per cent protein with 12 to 18.5 per cent fat. It is used as a gripe water given to colicky infants. It is used to relieve bronchial spasms because of its antispasmodic properties. It targets the smooth muscles of the respiratory system, stomach muscles and intestines. Herbalists have used it for centuries to induce milk production in nursing mothers. Rajasthan is the third largest producer of spices in the country and accounts for 12.48 of the total production of major spices. The state produces about $6,96,700$ tones of seed spices from an area of 9,01,628 ha with productivity $4,832 \mathrm{~kg} / \mathrm{ha}$.

The major fennel producing districts of Rajasthan are Nagaur, Sirohi, Jalore, Dausa, Tonk, Sawai Madhopur and occupy above 90 per cent of area and production of fennel crop. The average area, production and productivity of last five years are 13,404 ha, 11,085 tones, $827 \mathrm{~kg} / \mathrm{ha}$ respectively (Anonymous. 201011). So there are possibilities to increase its production by 40 to 50 per cent by adoption of improved technologies.

Fennel is an important commercial cash crop of arid and semi arid region. The production of spices is largely in the hands of small and marginal farmers and the level of productivity of most of the spices in India is below the level as prevailing in other countries. The lower productivity is attributed to lack of knowledge of high yielding varieties, ravages due to pest and diseases, inadequate postharvest technology and poor processing and storage facilities. Keeping this fact in view the present study entitled "The knowledge and Adoption of Recommended Production Technology of Fennel Cultivation by the Farmers in Nagaur District of Rajasthan" was undertaken.

\section{Materials and Methods}

The present investigation was conducted in purposively selected Nagaur district of Rajasthan state highest area and great potential of increasing production and productivity. The researches himself is resident of the area and acquainted with the farmers and their local dialect which facilitated easy rapport building and authentic data collection from the farmers. 
The selected consist of twelve tehsils, Out of which two tehsils namely Mertacity and Degana with maximum area under fennel crop production were selected for the study purpose. Separate lists of gram panchayats of the selected tehsils were prepared with the help of concerned 'patwaries' of the Mertacity and Degana tehsils. Mertacity and Degana tehsils comprise of 42 and 34 gram panchayats respectively. Out of which two gram panchayats (Dava and Jaroda kala) from Mertacity tehsil and two gram panchayats (Sanjoo and Chonsli) from Degana tehsil were selected on proportionate random basis.

Initially, a complete list of all the major fennel growing villages of the selected tehsils was prepared in consultation with the personnel of revenue department and Agriculture department of the concerned area. From the list so prepared, 4 villages from each Tehsil were identified on the random basis under fennel crop. Thus, in all eight villages were selected for the present investigation.

A comprehensive list of all fennel growers was prepared separately for all selected villages of identified tehsils. In preparing the list, the help of revenue personnel and agricultural supervisor of the concerned area was taken for authenticity and counter check of information. Then after the farmers were categorized in to three categories i.e. large, small and marginal farmers.

Following the procedure laid down above a sample of total 15 respondents i.e. 5 in each category from every selected village was drawn randomly. Thus the study sample for the present investigation was comprised 120 respondents. (i.e. 60 from each Tehsil). Keeping in mind the objectives of study, the interview schedule was developed for the collection of data from the selected respondents.

\section{Association between selected personal variables of the respondents with their level of knowledge of recommended fennel production technology}

This section of the chapter deals with the association between the level of knowledge and selected personal variables viz., age, education, annual income, caste, size of land holding, family type and family size of fennel growers. To find out the association between these personal characteristics and the level of knowledge, chi-square test was applied. The results have been presented in subsequent tables.

\section{Association between age of the respondents and level of knowledge}

\section{Hypothesis}

\begin{tabular}{|l|l|l|}
\hline $\mathrm{NH}_{11}$ & $:$ & $\begin{array}{l}\text { There is no association between } \\
\text { age of respondents and knowledge } \\
\text { of fennel production technology. }\end{array}$ \\
\hline $\mathrm{RH}_{11}$ & $:$ & $\begin{array}{l}\text { There is an association between age } \\
\text { of respondents and knowledge of } \\
\text { fennel production technology. }\end{array}$ \\
\hline
\end{tabular}

An observation of data in table 1 shows that out of total 19 respondents in age group less than 35 years, $8(42.11 \%), 8(42.11 \%)$ and 3 $(15.789 \%)$ were having low, medium and high level of knowledge of improved fennel cultivation technology respectively. In the age group of 35 to 53 years, 25 (59.52\%), $10(23.81 \%)$ and $7(16.67 \%)$ farmers had low, medium and high level of knowledge respectively. While, in the age group of above 53 years, 7(11.86\%), $22(37.29 \%)$ and 30 $(50.85 \%)$ respondents possessed low, medium and high level of knowledge of improved practices of fennel cultivation, respectively.

The data in table 1 further indicate that the calculated chi-square value (29.782) was higher than tabulated value therefore, the null 
hypothesis $\left(\mathrm{NH}_{11}\right)$ was rejected. This reveals that there existed an association between age of respondents and knowledge of fennel production technology.

The present finding is in conforming to that of Kumar et al., (2013) who revealed that antecedent variables like knowledge and age, education level, and size of land holding were found to be positively and significantly associated with the knowledge level of farmers about coriander production technology.

Association between education and level of knowledge of recommended fennel production technology

\section{Hypothesis}

\begin{tabular}{|l|l|l|}
\hline $\mathrm{NH}_{12}$ & $:$ & $\begin{array}{l}\text { There is no association between } \\
\text { education of respondents and } \\
\text { knowledge of fennel production } \\
\text { technology. }\end{array}$ \\
\hline $\mathrm{RH}_{12}$ & $: \begin{array}{l}\text { There is an association between } \\
\text { education of respondents and } \\
\text { knowledge of fennel production } \\
\text { technology. }\end{array}$ \\
\hline
\end{tabular}

The results in table 2 indicate that out of total 19 fennel growers in illiterate group, 5 (26.32\%), $4(21.00 \%)$ and $10 \quad(52.63 \%)$ possessed low, medium and high level of knowledge of improved practices of fennel cultivation respectively. In the group of up to primary level, 12 (35.29\%), 14 (41.18\%), and $8(23.53 \%)$ respondents had low, medium and high level of knowledge respectively. In the group of primary level to middle level of education, 11 (61.11\%), $2(11.00 \%)$ and 5 $(27.78 \%)$ respondents reported in low, medium and high level of knowledge respectively. While, in the group of above middle level of education, 12 (24.49\%), 20 $(40.82 \%)$ and $17(34.69 \%)$ respondents were observed in low, medium and high level of knowledge about improved fennel cultivation technology.

Further the data in table 2 indicate that the calculated chi-square value (13.910) was higher than tabulated value therefore, the null hypothesis $\left(\mathrm{NH}_{12}\right)$ was rejected. This reveals that there existed an association between education of respondents and knowledge of fennel production technology.

The present finding is in conformity with that of Kumar et al., (2013) who revealed that antecedent variables like knowledge and age, education level, and size of land holding were found to be positively and significantly associated with the knowledge level of farmers about coriander production technology.

Association between annual income of respondents and level of knowledge of recommended fennel production technology

\section{Hypothesis}

$\mathrm{NH}_{13}:$ : $\quad$ There is no association between annual income of respondents and knowledge of fennel production technology.

$\mathrm{RH}_{13}:$ There is an association between annual income of respondents and knowledge of fennel production technology.

The data accorded in table 3 show that 36 $(57.14 \%), 23(36.51 \%)$ and $4(6.35 \%)$ less than 90,000 income farmers had low, medium and high level of knowledge about fennel production technology respectively. Whereas, 90,000 to 1,75,000annual income farmers who possessed low, medium and high level of adoption were 2 (14.29\%),7 (50.00\%) and $5(35.71 \%)$ respectively. In the income category of more than 1,75,000, $2(4.65 \%), 10$ $(23.26 \%)$ and $31(72.09 \%)$ farmers were 
observed in the low, medium and high knowledge category, respectively.

Further the data in table 3 indicate that the calculated chi-square value (58.683) was higher than tabulated value, therefore, the null hypothesis $\left(\mathrm{NH}_{13}\right)$ was rejected. This reveals that there existed an association between annual income of respondents and knowledge of fennel production technology.

The present finding is in conformity with that of Kumar et al., (2013) who revealed that antecedent variables like knowledge and age, education level, and size of land holding were found to be positively and significantly associated with the knowledge level of farmers about coriander production technology.

Association between caste of respondents and level of adoption of recommended fennel production technology

\section{Hypothesis}

\begin{tabular}{|l|l|l|}
\hline $\mathrm{NH}_{14}$ & $:$ & $\begin{array}{l}\text { There is no association between } \\
\text { caste of respondents and knowledge } \\
\text { of fennel production technology. }\end{array}$ \\
\hline $\mathrm{RH}_{14}:$ & $\begin{array}{l}\text { There is an association between } \\
\text { caste of respondents and knowledge } \\
\text { of fennel production technology. }\end{array}$ \\
\hline
\end{tabular}

The data in table 4 indicate that out of total 29 fennel growers in scheduled caste 11 (37.93\%), 10 (34.48\%) and 8 (27.59\%) possessed low, medium and high level of knowledge respectively about improved practices of fennel production. In the group of OBC12 (26.67\%), 15 (33.33\%) and 18 $(40.00 \%)$ respondents had low, medium and high level of knowledge about fennel production technology. Whereas, in the group of general 17 (36.96\%), 15 (32.61\%) and $14(30.43 \%)$ respondents had low, medium and high level of knowledge about fennel production technology.

It could be further observed from table 4 that calculated chi-square value (1.987) was less than tabulated value. Therefore, the null hypothesis $\left(\mathrm{NH}_{14}\right)$ was accepted. This reveals that there is no association between caste of respondents and knowledge of fennel production technology. It could be inferred that caste did not play a significant role in knowledge level of fennel production technology among the farmers of the study area. The present finding is in conformity with that of Kumar et al., (2013) revealed that farmer's knowledge and caste, family size, and family type were found to be non significantly associated with regard to recommended coriander production technology. The findings of this study could be supported by the findings of Chodhary (1999), Meena (2001), Jaitawat and Sharma (2008), Jangid (2001) Mahendra singh (2012) and Surendra kumar (2013).

\section{Association between size of land holding of respondents and level of knowledge of recommended fennel production technology}

\section{Hypothesis}

\begin{tabular}{|l|l|l|}
\hline $\mathrm{NH}_{15}$ & $:$ & $\begin{array}{l}\text { There is no association between } \\
\text { size of land holding of respondents } \\
\text { and knowledge of fennel } \\
\text { production technology. }\end{array}$ \\
\hline $\mathrm{RH}_{15}:$ & $\begin{array}{l}\text { There is an association between } \\
\text { size of land holding of respondents } \\
\text { and knowledge of fennel } \\
\text { production technology. }\end{array}$ \\
\hline
\end{tabular}

The data accorded in table 5 show that 9 $(22.50 \%) 10 \quad(25.00 \%)$ and 21 (52.50\%) marginal farmers had low, medium and high level of knowledge about fennel production technology respectively. Whereas, small farmers who possessed low, medium and high 
level of knowledge were $8(20.00 \%), 12$ $(30.00 \%)$ and $20(50.00 \%)$ respectively. In the category of large farmers, 5 (12.50\%), 17 $(42.50 \%)$ and $18(45.00 \%)$ farmers were observed in the low, medium and high knowledge category, respectively. The data further show that calculated chi-square value (3.419) was less than tabulated value. Thus, the null hypothesis $\left(\mathrm{NH}_{15}\right)$ was accepted and research hypothesis was rejected. This nonsignificant value shows that there is no association between size of land holding and knowledge of fennel production technology. Hence, it is concluded that land holding did not play a significant role in knowledge of fennel production technology in the study area.

The present finding is in conformity with that of Kumar et al., (2013) revealed that farmer's knowledge and caste, family size, and family type were found to be non - significantly associated with regard to recommended coriander production technology.

Association between family type of respondents and level of knowledge of recommended fennel production technology

\section{Hypothesis}

\begin{tabular}{|l|l|l|}
\hline $\mathrm{NH}_{16}$ & $:$ & $\begin{array}{l}\text { There is no association between } \\
\text { family type of respondents and } \\
\text { knowledge of fennel production } \\
\text { technology. }\end{array}$ \\
\hline $\mathrm{RH}_{16}:$ & $: \begin{array}{l}\text { There is an association between } \\
\text { family type of respondents and } \\
\text { knowledge of fennel production } \\
\text { technology. }\end{array}$ \\
\hline
\end{tabular}

The data in table 6 indicate that out of total 67 fennel growers in single family composition 18 (26.87\%), 22 (32.84\%) and 27 (40.298\%) possessed low, medium and high level of knowledge respectively about improved practices of fennel production. In the group of joint family composition 22 (41.51\%), 18 $(33.96 \%)$ and $13(24.53 \%)$ respondents had low, medium and high level of knowledge about fennel production technology.

It could be further observed from table 6 that calculated chi-square value (4.123) was less than tabulated value. Therefore, the null hypothesis $\left(\mathrm{NH}_{16}\right)$ was accepted. This reveals that there is no association between family type of respondents and knowledge of fennel production technology. It could be inferred that family type did not play a significant role in knowledge level of fennel production technology among the farmers of the study area.

The present finding is in conformity with that of Kumar et al., (2013) revealed that farmer's knowledge, caste, family size and family type were found to be non - significantly associated with regard to recommended coriander production technology.

Association between family size of respondents and level of knowledge of recommended fennel production technology

\section{Hypothesis}

\begin{tabular}{|l|l|l|}
\hline $\mathrm{NH}_{17}$ & $:$ & $\begin{array}{l}\text { There is no association between } \\
\text { family size of respondents and } \\
\text { knowledge of fennel production } \\
\text { technology. }\end{array}$ \\
\hline $\mathrm{RH}_{17}:$ & $\begin{array}{l}\text { There is an association between } \\
\text { family size of respondents and } \\
\text { knowledge of fennel production } \\
\text { technology. }\end{array}$ \\
\hline
\end{tabular}


Table.1 Association between age of respondents and level of knowledge of recommended fennel production technology

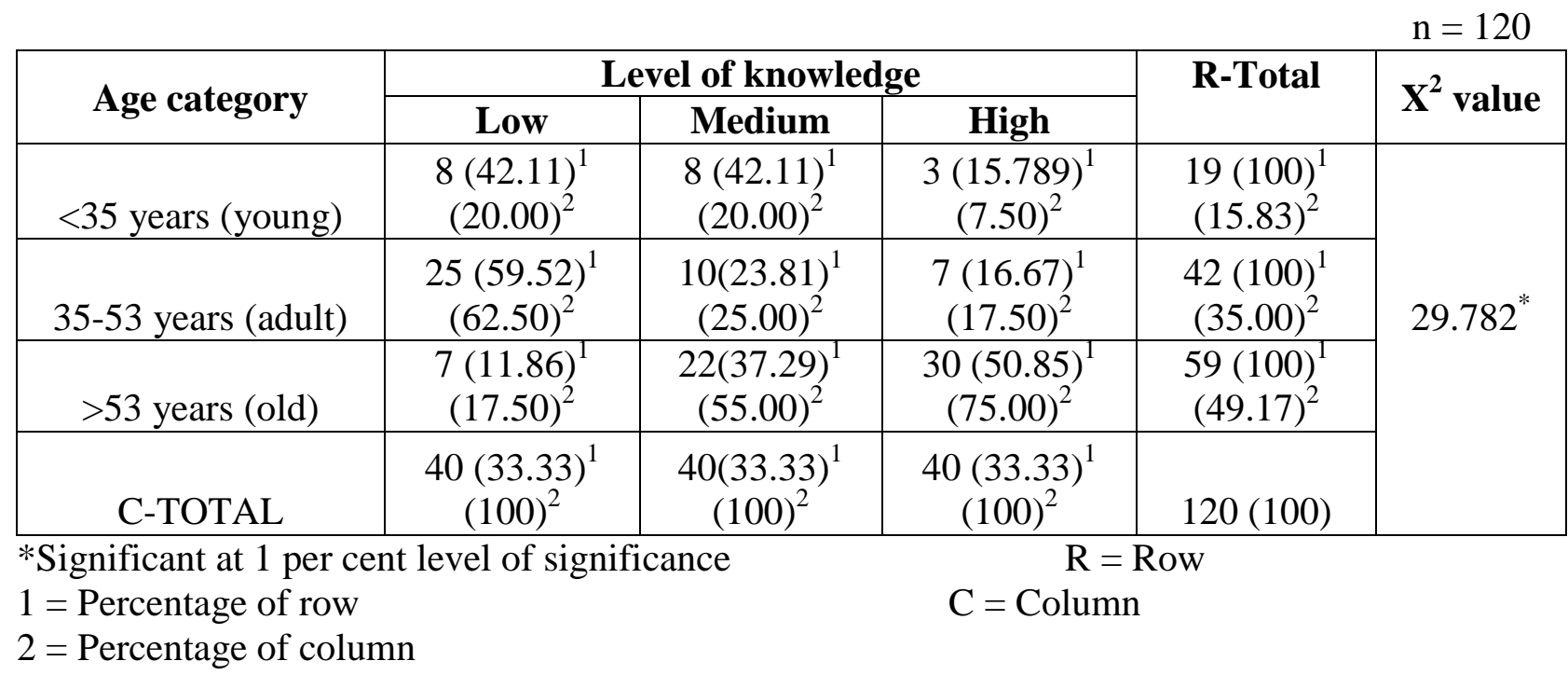

Table.2 Association between education of respondents and level of knowledge of recommended fennel production technology

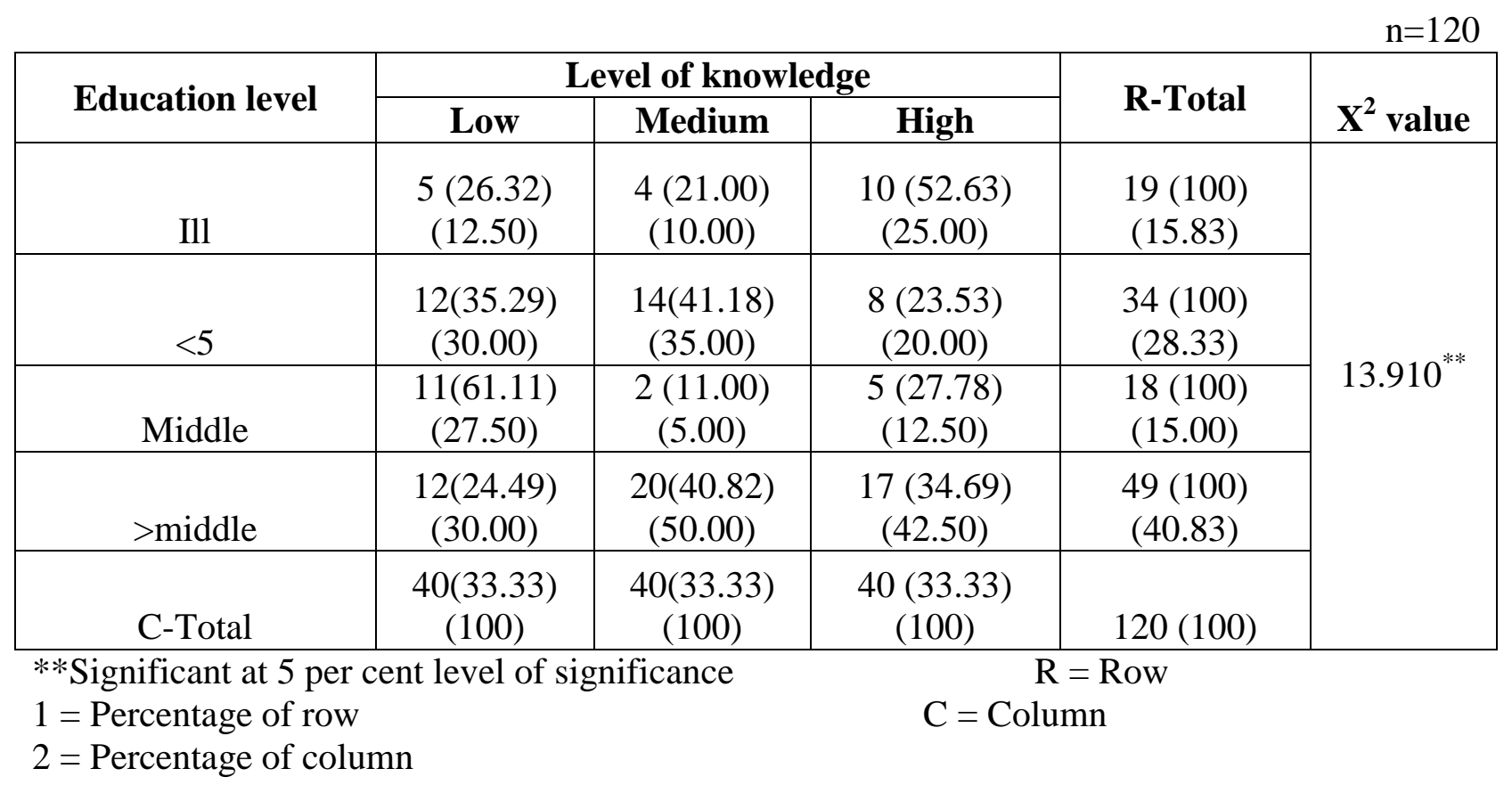


Table.3 Association between annual income of respondents and level of knowledge of recommended fennel production technology

\begin{tabular}{|c|c|c|c|c|c|}
\hline \multirow{2}{*}{$\begin{array}{c}\text { Annual income } \\
\text { group }\end{array}$} & \multicolumn{3}{|c|}{ Level of knowledge } & \multirow{2}{*}{ R-Total } & \multirow[b]{2}{*}{$\mathrm{X}^{2}$ value } \\
\hline & Low & Medium & High & & \\
\hline$<90000$ & $\begin{array}{c}36(57.14) \\
(90.00)\end{array}$ & $\begin{array}{c}23(36.51) \\
(57.50)\end{array}$ & $\begin{array}{l}4(6.35) \\
(10.00)\end{array}$ & $\begin{array}{l}63(100) \\
(52.50)\end{array}$ & \multirow{4}{*}{$58.683 *$} \\
\hline $90000-175000$ & $\begin{array}{c}2(14.29) \\
(5.00)\end{array}$ & $\begin{array}{c}7(50.00) \\
(17.50) \\
\end{array}$ & $\begin{array}{c}5(35.71) \\
(12.50) \\
\end{array}$ & $\begin{array}{c}14(100) \\
(11.67) \\
\end{array}$ & \\
\hline$>1.75$ lakh & $2(4.65)(5.00)$ & $\begin{array}{c}10(23.26) \\
(25.00) \\
\end{array}$ & $\begin{array}{c}31(72.09) \\
(77.50) \\
\end{array}$ & $\begin{array}{c}43(100) \\
(35.83) \\
\end{array}$ & \\
\hline C-total & $\begin{array}{c}40(33.33) \\
(100)\end{array}$ & $\begin{array}{c}40(33.33) \\
(100)\end{array}$ & $\begin{array}{c}40(33.33) \\
(100)\end{array}$ & $120(100)$ & \\
\hline \multicolumn{4}{|c|}{ *Significant at 1 per cent level of significance } & \multicolumn{2}{|l|}{$\mathrm{R}=\mathrm{Row}$} \\
\hline $\begin{array}{l}1=\text { Percentage of } \\
2=\text { Percentage of }\end{array}$ & $\begin{array}{l}\text { row } \\
\text { column }\end{array}$ & & & umn & \\
\hline
\end{tabular}

Table.4 Association between caste of respondents and level of knowledge of recommended fennel production technology

\begin{tabular}{|c|c|c|c|c|c|}
\hline \multirow{2}{*}{ Caste } & \multicolumn{3}{|c|}{ Level of knowledge } & \multirow{2}{*}{ R-Total } & \multirow{2}{*}{$\mathrm{X}^{2}$ value } \\
\hline & Low & Medium & High & & \\
\hline Sc & $\begin{array}{c}11(37.93)^{1} \\
(27.50)^{\mathbf{2}}\end{array}$ & $\begin{array}{c}10(34.48) \\
(25.00)\end{array}$ & $\begin{array}{c}8(27.59)^{\mathbf{1}} \\
(20.00)^{2}\end{array}$ & $\begin{array}{c}29(100)^{1} \\
(24.17)^{2} \\
\end{array}$ & \multirow{4}{*}{$1.987^{\mathrm{NS}}$} \\
\hline $\mathrm{OBC}$ & $\begin{array}{c}12(26.67)^{\mathbf{1}} \\
(30.00)^{\mathbf{2}}\end{array}$ & $\begin{array}{c}15(33.33)^{1} \\
(37.50)^{2}\end{array}$ & $\begin{array}{c}18(40.00)^{\mathbf{1}} \\
(45.00)^{\mathbf{2}}\end{array}$ & $\begin{array}{c}45(100)^{\mathbf{1}} \\
(37.50)^{2}\end{array}$ & \\
\hline Gen & $\begin{array}{c}17(36.96)^{\mathbf{1}} \\
(42.50)^{2}\end{array}$ & $\begin{array}{c}15(32.61)^{1} \\
(37.50)^{2}\end{array}$ & $\begin{array}{c}14(30.43)^{\mathbf{1}} \\
35.00)^{\mathbf{2}}\end{array}$ & $\begin{array}{c}46(100)^{1} \\
(38.33)^{2}\end{array}$ & \\
\hline C-Total & $\begin{array}{c}40(33.33)^{1} \\
(100)^{\mathbf{2}} \\
\end{array}$ & $\begin{array}{c}40(33.33)^{1} \\
(100)^{2}\end{array}$ & $\begin{array}{c}40(33.33)^{\mathbf{1}} \\
(100)^{2}\end{array}$ & $120(100)$ & \\
\hline
\end{tabular}

NS = Non-significant

$1=$ Percentage of row

$2=$ Percentage of column
$\mathrm{R}=\mathrm{Row}$

$\mathrm{C}=$ Column 
Table.5 Association between size of land holding of respondents and level of knowledge of recommended fennel production technology

\begin{tabular}{|c|c|c|c|c|c|}
\hline \multirow{2}{*}{$\begin{array}{l}\text { Size of Land } \\
\text { holding }\end{array}$} & \multicolumn{3}{|c|}{ Level of knowledge } & \multirow{2}{*}{ R-Total } & \multirow[b]{2}{*}{$\mathrm{X}^{2}$ value } \\
\hline & Low & Medium & High & & \\
\hline $\begin{array}{c}\text { Marginal } \\
\text { farmers }\end{array}$ & $\begin{array}{c}9(22.50)^{1} \\
(40.91)^{2}\end{array}$ & $\begin{array}{c}10(25.00)^{1} \\
(25.64)^{2}\end{array}$ & $\begin{array}{c}21(52.50)^{1} \\
(35.59)^{2}\end{array}$ & $\begin{array}{c}40(100)^{1} \\
(33.33)^{2}\end{array}$ & \multirow{3}{*}{$3.419^{\mathrm{NS}}$} \\
\hline Small farmers & $\begin{array}{c}8(20.00)^{1} \\
(36.36)^{2}\end{array}$ & $\begin{array}{c}12(30.00)^{1} \\
(30.77)^{2}\end{array}$ & $\begin{array}{c}20(50.00)^{1} \\
(33.89)^{2}\end{array}$ & $\begin{array}{c}40(100)^{1} \\
(33.33)^{2}\end{array}$ & \\
\hline Large farmers & $\begin{array}{c}5(12.50)^{1} \\
(22.72)^{2}\end{array}$ & $\begin{array}{c}17(42.50)^{1} \\
(43.59)^{2}\end{array}$ & $\begin{array}{c}18(45.00)^{1} \\
(30.51)^{2}\end{array}$ & $\begin{array}{c}40(100)^{1} \\
(33.33)^{2}\end{array}$ & \\
\hline C-Total & $\begin{array}{c}22(18.33)^{1} \\
(100)^{2}\end{array}$ & $\begin{array}{c}39(32.50)^{1} \\
(100)^{2}\end{array}$ & $\begin{array}{c}59(49.17)^{1} \\
(100)^{2}\end{array}$ & $120(100)$ & \\
\hline
\end{tabular}

NS = Non-significant $; \mathrm{R}=$ Row $; \mathrm{C}=$ Colum

$1=$ Percentage of row; $2=$ Percentage of column

Table.6 Association between family type of respondents and level of knowledge of recommended fennel production technology

\begin{tabular}{|c|c|c|c|c|c|}
\hline \multirow{3}{*}{ Family type } & \multirow{2}{*}{\multicolumn{3}{|c|}{ Level of knowledge }} & \multicolumn{2}{|c|}{$\mathrm{n}=120$} \\
\hline & & & & & $\mathrm{Y}^{2}$ voluo \\
\hline & Low & Medium & High & R-Total & $x-$ value \\
\hline Single & $\begin{array}{c}18(26.87)^{1} \\
(45.00)^{2}\end{array}$ & $\begin{array}{c}22(32.84)^{\top} \\
(55.00)^{2}\end{array}$ & $\begin{array}{c}27(40.298)^{1} \\
(67.50)^{2}\end{array}$ & $\begin{array}{c}67(100)^{1} \\
(55.83)^{2}\end{array}$ & \\
\hline Joint & $\begin{array}{c}22(41.51)^{1} \\
(55.00)^{2}\end{array}$ & $\begin{array}{c}18(33.96)^{1} \\
(45.00)^{2}\end{array}$ & $\begin{array}{c}13(24.53)^{1} \\
(32.50)^{2}\end{array}$ & $\begin{array}{c}53(100)^{1} \\
(44.17)^{2}\end{array}$ & $4.123^{\mathrm{NS}}$ \\
\hline C-Total & $\begin{array}{c}40(33.33)^{1} \\
(100)^{2}\end{array}$ & $\begin{array}{c}40(33.33)^{1} \\
(100)^{2}\end{array}$ & $\begin{array}{c}40(33.33)^{1} \\
(100)^{2}\end{array}$ & $120(100)$ & \\
\hline
\end{tabular}

NS $=$ Non-significant $; \mathrm{R}=$ Row $; \mathrm{C}=$ Colum

$1=$ Percentage of row; $2=$ Percentage of column

Table.7 Association between family size of respondents and level of knowledge of recommended fennel production technology

\begin{tabular}{|c|c|c|c|c|c|}
\hline \multirow{3}{*}{ Family size } & & & & \multicolumn{2}{|c|}{$\mathrm{n}=120$} \\
\hline & \multicolumn{3}{|c|}{ Level of knowledge } & & $\mathrm{Y}^{2}$ voluo \\
\hline & Low & Medium & High & K-1 otal & $x$ value \\
\hline Small & $\begin{array}{c}12(27.27)^{\mathrm{I}} \\
(30.00)^{2}\end{array}$ & $\begin{array}{c}15(34.00)^{\mathrm{T}} \\
(37.50)^{2}\end{array}$ & $\begin{array}{c}17(38.64)^{\mathrm{T}} \\
(42.50)^{2}\end{array}$ & $\begin{array}{c}4(100)^{1} \\
(36.67)^{2}\end{array}$ & $1.364^{\mathrm{NS}}$ \\
\hline Large & $\begin{array}{c}28(36.84)^{1} \\
(70.00)^{2}\end{array}$ & $\begin{array}{c}25(32.89)^{1} \\
(62.50)^{2}\end{array}$ & $\begin{array}{c}23(30.26)^{1} \\
(57.50)^{2}\end{array}$ & $\begin{array}{l}76(100)^{1} \\
(63.33)^{2}\end{array}$ & \\
\hline C-Total & $\begin{array}{c}40(33.33)^{1} \\
(100)^{2}\end{array}$ & $\begin{array}{c}40(33.33)^{\top} \\
(100)^{2}\end{array}$ & $\begin{array}{c}40(33.33)^{1} \\
(100)^{2}\end{array}$ & $120(100)$ & \\
\hline
\end{tabular}

$\mathrm{NS}=$ Non-significant $; \mathrm{R}=$ Row $; \mathrm{C}=$ Colum

$1=$ Percentage of row; 2 = Percentage of column 
The data in table 7 indicate that out of total 44 fennel growers in small family composition $12(27.27 \%), 15(34.00 \%)$ and $17(38.64 \%)$ possessed low, medium and high level of knowledge respectively about improved practices of fennel production. In the group of large family composition 28 (36.84), 25 $(32.89 \%)$ and $23(30.26 \%)$ respondents had low, medium and high level of knowledge about fennel production technology. It could be further observed from table 7 that calculated chi-square value (1.364) was less than tabulated value. Therefore, the null hypothesis $\left(\mathrm{NH}_{17}\right)$ was accepted. This reveals that there is no association between family size of respondents and knowledge of fennel production technology. It could be inferred that family size did not play a significant role in knowledge level of fennel production technology among the farmers of the study area.

The present finding is in conformity with that of Kumar et al., (2013) revealed that farmer's knowledge and caste family size and family type were found to be non - significantly associated with regard to recommended coriander production technology.

In conclusion, the age, education and annual income were found to be positive and significantly associated with the knowledge level of farmers about fennel production technology. While, the variables like, caste, size of land holding, family type and family size were found to be non-significantly associated with the knowledge level of farmers about fennel production technology.

\section{References}

Anonymous. 2010-11. Indian Economy. Anonymous. 2010-11. Spices Board and CMIE.

Anonymous. 2011-12. Agricultural Statistics, Directorate of Economics and Statistics, Department of Agriculture and Cooperation, Government of India, New Delhi.

Anonymous. 2011-12. Vital Agriculture Statistics, Dept. of Agriculture, GOR, Pant Krishi Bhawan, Jaipur.

Bangarva, G.S., Khan, I.M., Jhajharia, A.K. Singh, C. and Kumari, S. 2009. Study on association between extent of utilization of chemical fertilizers and selected independent variables in spices crops of Rajasthan. Proceeding of National Seminar on Information Technology Application in Agriculture for Livelihood Security of Farmers organized by Rajasthan Society of Extension Education \& DEE, Udaipur from Nov. 10-12:120-121.

Jaitawat, V.S. and Sharma, K.D. 2008. Association on between level of knowledge of cultivators regarding recommended cumin cultivation technology and selected independent variables. Indian J. Social Res., 49: 8392.

Kumar S., Lal H. and Bunker H.S. 2013. "Association between the selected independent variables and their knowledge of recommended coriander production technology". Indian $J$. Social Res., vol. 54(4): 337-344.

\section{How to cite this article:}

Sunil Kumar Sharma, N.K. Sharma, Anand Kumar, Deepak Chaturvedi. 2017. Association between the Selected Independent Variables and the Knowledge Level of Farmers about Recommended Production Technology of Fennel. Int.J.Curr.Microbiol.App.Sci. 6(5): 23752384. doi: https://doi.org/10.20546/ijcmas.2017.605.266 